\title{
Reformasi Pelayanan Publik di Dinas Investasi dan Pelayanan Terpadu Satu Pintu Kota Gorontalo
}

\begin{abstract}
This study aims is to analyze; 1) Public service reform at the Department of Investment and One Gate Integrated Services Gorontalo City; 2) Determinant factors affecting public service reform at the Department of Investment and One Gate Integrated Services Gorontalo City. The research method used qualitative research, data collecting technique by observation, interview and documentation. The results showed that; 1). Public service reform at the Department of Investment and One Gate Integrated Services Gorontalo City seen from structure, procedure, process not yet run well but from behavioral element already showed existence of change of attitude of good apparatus in giving services; 2). The determinant factors affecting public service reform at the Capital Market and Department of Investment and One Gate Integrated Services Gorontalo City need to pay attention to the supporting factors of public service reform related to; 1) the awareness of the police officers in service; 2) rule enforcement; 3) organization; 4) income of employee; 5) human skill and resources; 6) facilities.
\end{abstract}

Keywords: Public Service; Gorontalo.

\begin{abstract}
ABSTRAK
Penelitian ini bertujuan untuk menganalisis; 1) Reformasi layanan publik di Departemen Investasi dan Pelayanan Terpadu Satu Pintu Kota Gorontalo; 2) Faktor determinan yang mempengaruhi reformasi pelayanan publik di Departemen Investasi dan Pelayanan Terpadu Satu Pintu Kota Gorontalo. Metode penelitian yang digunakan adalah penelitian kualitatif, teknik pengumpulan data dengan observasi, wawancara dan dokumentasi. Hasilnya menunjukkan bahwa; 1). Reformasi pelayanan publik pada Dinas Investasi dan Pelayanan Terpadu Satu Pintu Kota Gorontalo dilihat dari struktur, prosedur, proses yang belum berjalan dengan baik tetapi dari unsur perilaku sudah menunjukkan adanya perubahan sikap aparatur yang baik dalam memberikan pelayanan; 2). Faktor-faktor penentu yang mempengaruhi reformasi pelayanan publik di Pasar Modal dan Departemen Investasi dan Pelayanan Terpadu Satu Pintu Kota Gorontalo perlu memperhatikan faktor-faktor pendukung reformasi layanan publik terkait; 1) kesadaran petugas polisi dalam pelayanan; 2) penegakan aturan; 3) organisasi; 4) pendapatan karyawan; 5) keterampilan dan sumber daya manusia; 6) fasilitas.
\end{abstract}

Kata Kunci: Pelayanan Publik; Gorontalo. 


\section{PENDAHULUAN}

Pelayanan publik memiliki implikasi yang luas dari berbagai aspek kehidupan. Dalam kehidupan politik misalnya, perbaikan pelayanan publik akan berdampak pada tumbuhnya kepercayaan dan partisipasi masyarakat terhadap pemerintah. Sebaliknya pelayanan publik yang buruk akan menjadi salah satu faktor munculnya krisis kepercayaan masyarakat kepada pemerintah. Perbaikan pelayanan publik diharapkan akan memperbaiki kembali citra pemerintahan di mata masyarakat.

Dalam kehidupan ekonomi, reformasi pelayanan publik akan dapat memperbaiki iklim investasi yang sangat diperlukan untuk lebih menggairahkan lagi sektor perekonomian. Oleh karena itu pemerintah harus dapat menarik minat para investor untuk menanamkan modalnya di daerah. Pemerintah sangat membutuhkan para investor yang menanamkan modalnya di daerah untuk menggerakkan perekonomian daerah. Dengan adanya para investor tersebut dapat membuka lapangan kerja didaerah, sehingga masalah penggangguran juga dapat teratasi, dan perekonomian daerah maju sehingga daerah tersebut dapat cepat berkembang dan masyarakat hidup sejahtera.

Tuntutan masyarakat akan pelayanan publik yang berkualitas mengharuskan pembenahan dalam tubuh pemerintah. Masih tingginya tingkat keluhan masyarakat sebagai pengguna jasa dan penerima layanan menunjukkan pemerintah belum sepenuhnya mampu menciptakan sistem pelayanan publik yang baik sehingga membawa dampak menurunnya kepercayaan publik terhadap pemerintah. Keputusan Menteri Pendayagunaan Aparatur Negara Nomor. 63/KEP/M.PAN/7/Tahun 2003 tentang Pedoman Umum Penyelenggaraan Pelayanan Publik yang memuat asas-asas pelayanan publik seperti transparansi, akuntabilitas, kondisional, partisipatif, kesamaan hak serta keseimbangan hak dan kewajiban. Demikian pula dalam UndangUndang Pelayanan Publik Nomor 25 Tahun 2009 pemerintah lebih mempertegas tentang penyelenggaraan pelayanan publik yang selanjutnya disebut penyelenggaraan negara, korporasi, lembaga independen yang dibentuk berdasarkan undang-undang untuk kegiatan pelayanan publik dan badan hukum lain yang dibentuk semata-mata untuk kegiatan pelayanan publik. Semua aturan di atas adalah merupakan upaya pemerintah dalam memperbaiki sistim pelayanan pada umumnya khususnya pelayanan dalam bidang perizinan.

Dinas Penanaman Modal dan Pelayanan Terpadu Satu Pintu Kota Gorontalo merupakan salah satu perangkat pemerintah daerah di Kota Gorontalo yang menerapkan sistem pelayanan satu pintu. Dinas Penanaman Modal dan Pelayanan Terpadu Satu Pintu Kota Gorontalo sebagai instansi yang khusus bertugas memberikan pelayanan mengenai perizinan yang langsung bersinggungan kepada masyarakat, pada dasarnya dapat dikatakan sebagai terobosan untuk mereformasi sistim pelayanan perizinan diharapkan mampu memberikan pelayanan publik yang berkualitas sesuai dengan tuntutan dan harapan masyarakat. Pembentukan Dinas Penanaman Modal dan Pelayanan Terpadu Satu Pintu Kota Gorontalo sebagai wujud nyata komitmen pemerintah Kota Gorontalo dalam melaksanakan kebijakan pemerintah pusat di daerah yaitu memberikan pelayanan yang baik dan memberikan pelayanan secara terpadu sehingga memudahkan masyarakat dan dunia usaha dalam memperoleh perizinan. 
Berdasarkan hasil pengamatan penulis dan didukung oleh berbagai informasi, reformasi pelayanan publik di Dinas Penanaman Modal dan Pelayanan Terpadu Satu Pintu Kota Gorontalo dihadapkan pada berbagai permasalahan, hal ini terlihat dari masih banyaknya keluhan dan pengaduan dari masyarakat baik secara langsung maupun tidak langsung melalui media massa berkaitan tingginya biaya yang harus dibayarkan. Masyarakat yang mengurus surat izin usaha harus membayar sebesar Rp 2.000.000,- (dua juta rupiah ) untuk mendapatkan surat izin untuk usahanya. Demikian pula banyaknya persyaratan yang harus dipenuh yaitu ada kurang lebih 10 persyaratan yang harus dilengkapi oleh pemohon/masyarakat yang mengurus perizinan.

Banyaknya persyaratan yang harus dipenuhi oleh pemohon/masyarakat berpengaruh terhadap waktu penyelesaian pengurusan perizinan. Selain itu prosedur yang berbelit-belit ketika harus mengurus suatu perizinan sehingga masyarakat mengunakan jasa calo baik dari luar yang mengenal petugas atau dari dalam yaitu oknum pegawai itu sendiri untuk mempercepat proses penerbitan surat izin. Pengunaan calo oleh pemohon/masyarakat yang mengurus surat izin menyebabkan biaya pengurusan perizinan menjadi mahal, karena harus membayar jasa dari calo tersebut. Hal-hal inilah yang menimbulkan citra yang kurang baik di Dinas Penanaman Modal dan Pelayanan Terpadu Satu Pintu Kota Gorontalo khususnya dan pemerintah Daerah Kota Gorontalo pada umumnya.

\section{KAJIAN TEORI}

\subsection{Reformasi Pelayanan Publik}

Menurut Sinambela (2006:25) reformasi adalah perubahan dimana kedalamannya terbatas sedangkan keluasan perubahannya melibatkan seluruh masyarakat. Reformasi berarti perubahan dengan melihat keperluan masa depan, menekankan kembali pada bentuk asal, berbuat lebih baik dengan menghentikan penyimpangan-penyimpangan dan praktik yang salah atau memperkenalkan prosedur yang lebih baik, suatu perombakan menyeluruh dari suatu sistem kehidupan dalam aspek politik, ekonomi, hukum, sosial dan tentu saja termasuk bidang pendidikan. Reformasi juga berarti memperbaiki, membetulkan, menyempurnakan dengan membuat sesuatu yang salah menjadi benar. Oleh karena itu reformasi berimplikasi pada merubah sesuatu untuk menghilangkan yang tidak sempurna menjadi lebih sempurna seperti melalui perubahan kebijakan institusional. Reformasi adalah suatu usaha perubahan yang bertujuan merubah struktur, prosedur, proses serta tingkah laku agar pelayanan lebih berkualitas. Adapun penjelasannya adalah sebagai berikut:

\subsubsection{Struktur}

Struktur merupakan cara yang selaras dalam menempatkan manusia sebagai bagian organisasi pada suatu hubungan yang relative tetap yang sangat menentukan pola-pola interaksi, koordinasi, dan tingkah laku yang berorientasi pada tugas (Steers, 1984:70). Mempelajari struktur organisasi dapat mengetahui kemungkinan kegiatan-kegiatan apa yang ada dalam suatu organisasi, karena didalam suatu organisasi tergambar bagian-bagian (departemen) yang ada, nama dan posisi setiap manajer, dimana garis penghubung didalamnya menunjukan siapa atau bagian atau bertanggung jawab kepada siapa atau bagian apa. Struktur merupakan cara organisasi mengatur sumber daya manusia bagi 
kegiatan-kegiatan kearah tujuan. Struktur organisasi yang disusun dengan dengan baik akan menjadikan kualitas pelayanan yang baik tetapi apabila struktur organisasi tidak disusun dengan baik maka akan dapat menghambat kualitas pelayanan publik yang baik.

\subsubsection{Prosedur}

Pelayanan publik harus diberikan berdasarkan prosedur atau standar tertentu. Di dalam Kamus Besar Bahasa Indonesia, prosedur adalah spesifikasi teknis atau sesuatu yang dibakukan sebagai patokan dalam melakukan kegiatan. Dengan demikian, standar prosedur pelayanan publik adalah spesifikasi teknis pelayanan yang dibakukan sebagai patokan dalam melakukan pelayanan publik. Standar pelayanan publik tersebut merupakan ukuran atau persyaratan baku yang harus dipenuhi dalam penyelenggaraan pelayanan publik. Prosedur pelayanan wajib dimiliki oleh institusi penyelenggara layanan publik untuk menjamin diberikannya pelayanan yang berkualitas oleh penyedia layanan publik sehingga masyarakat penerima layanan merasakan adanya nilai yang tinggi atas pelayanan tersebut.

\subsubsection{Proses}

Proses merupakan aktivitas sumber kehidupan dalam struktur organisasi. Proses yang umum meliputi komunikasi, pengambilan keputusan, sosialisasi, dan pengembangan karier. Sedangkan proses dalam teori sistem adalah aktivitas teknik dan administratif yang berbaur untuk dijadikan masukan ditransformasikan menjadi keluaran (Gibson, Ivan Cevich, Donelly, 1995). Proses adalah urutan pelaksanaan atau kejadian yang terjadi secara alami atau didesain, mungkin menggunakan waktu, ruang, keahlian atau sumber daya lainnya, yang menghasilkan suatu hasil menjadi output (produk dan jasa) (Evans dan Lindsay, 2007:17). Soewarno Handayaningrat "mengatakan bahwa proses adalah sesuatu tuntutan perubahan dari suatu peristiwa perkembangan sesuatu yang dilakukan secara terus-menerus (Aoewarno, 1981: 2).

\subsubsection{Tingkah Laku}

Menurut Ribert Kwick (1974) tingkah laku adalah tindakan atau prilaku suatu organisme yang dapat diamati dan bahkan dapat dipelajari. Tingkah laku dapat dipelajari dengan berbagai cara, diantaranya dengan memperhatikan, mengayati, menerangkan apa yang terjadi dalam proses kejiwaan. Akan tetapi tidak ada cara tertentu untuk digunakan dalam semua keadaan karena proses kejiwaan itu sendiri itu tidak pernah sama. Sewaktu waktu ia dapat berubah sehingga tidak mungkin membagi-baginya, apalagi hendak memasukan kejiwaan itu kedalam golongan-golongan tertentu.

\subsection{Pelayanan Publik}

Keputusan Menteri Pendayagunaan Aparatur negara Nomor 63 Tahun 2003 pelayanan publik adalah segala kegiatan pelayanan yang dilaksanakan oleh penyelenggara pelayanan publik sebagai upaya pemenuhan kebutuhan penerima pelayanan maupun pelaksanaan ketentuan peraturan perundang-undangan. Di sisi lain, Lembaga Administrasi Negara (1998) pelayanan publik diartikan: "Sebagai segala bentuk kegiatan pelayanan umum yang dilaksanakan oleh Instansi Pemerintahan di Pusat dan Daerah, dan dilingkungan BUMN/BUMD dalam bentuk barang dan/atau jasa, baik dalam pemenuhan kebutuhan masyarakat maupun dalam rangkat pelaksanaan ketentuan peraturan perundang-undangan." 
Berdasarkan aturan-aturan diatas pelayanan publik atau pelayanan umum dapat didefinisikan sebagai segala bentuk jasa pelayanan, baik dalam bentuk barang publik maupun jasa publik yang pada prinsipnya menjadi tanggungjawab dan dilaksanakan oleh instansi pemerintah di Pusat, di daerah, dan di lingkungan Badan Usaha Miliki Negara atau Badan Usaha Milik Daerah, dalam rangka upaya pemenuhan kebutuhan masyarakat maupun dalam rangka pelaksanaan ketentuan peraturan perundangan pelaksanaan ketentuan peraturan perundang-undangan dalam rangka upaya pemenuhan kebutuhan masyarakat maupun dalam rangka pelaksanaan ketentuan peraturan perundang-undangan.

Humphreys (1998) mengatakan bahwa pelayanan publik adalah pelayanan yang utama atau lengkap yang dibiayai dari pajak. Frederickson (1988) menyebutkan apabila pelayanan publik dikaitkan dengan keadilan, maka bisa dibagi ke dalam tiga bentuk dasar, yaitu: (1) Pelayanan yang sama bagi semua. Misalnya pendidikan yang diwajibkan bagi penduduk usia muda. (2) Pelayanan yang sama secara proporsional bagi semua, yaitu distribusi pelayanan yang didasarkan atas suatu ciri tertentu yang berhubungan dengan kebutuhan. Misalnya jumlah polisi yang ditugaskan untuk berpatroli dalam wilayah tertentu berbeda-beda berdasarkan angka kriminalitas. (3) Pelayanan-pelayanan yang tidak sama bagi individu-individu bersesuaian dengan perbedaan yang relevan.

\subsection{Pelayanan Perizinan Terpadu Satu Pintu}

Sebagai upaya reformasi pelayanan perizinan, pemerintah berusaha menciptakan suatu sistem pelayanan yang optimal. Salah satu dari tindakan pemerintah tersebut adalah dengan dikeluarkannya suatu kebijakan Pelayanan Terpadu Satu Pintu (PTSP). Pelayanan Terpadu Satu Pintu adalah kegiatan penyelenggaraan perizinan dan non-perizinan, yang proses pengelolaannya di mulai dari tahap permohonan sampai tahap penerbitan dokumen, dilakukan secara terpadu dalam satu tempat. Dengan adanya Pelayanan Terpadu Satu Pintu (PTSP), aparatur pemberi pelayanan harus benar-benar ditata, diperbaharui, dan dibenahi untuk mengubah citra aparatur yang sebelumnya dipandang lamban dan tidak transparan menjadi efektif sesuai dengan tujuan pelayanan publik.

Peraturan Presiden Nomor 97 Tahun 2014 Pasal 1 ayat 1 menyatakan bahwa Pelayanan Terpadu Satu Pintu, yang selanjutnya disingkat PTSP adalah pelayanan secara terintegrasi dalam satu kesatuan proses dimulai dari tahap permohonan sampai dengan tahap penyelesaian produk pelayanan melalui satu pintu. Rumapea \& Surendro (dalam Hamid 2013: 88) mendefinisikan Pelayanan Terpadu Satu Pintu adalah kegiatan pelayanan perizinan dan non perizinan yang proses pegelolaannya mulai dari tahap permohonan sampai tahap terbitnya dokumen dilakukan dalam satu tempat. Penyelenggaraan Pelayanan Terpadu Satu Pintu merupakan perbaikan dari model pelayanan satu atap yang dilaksanakan sebelumnya. Dengan konsep ini, pemohon cukup datang ke satu tempat dan bertemu dengan petugas front office saja. Hal ini dapat meminimalisasikan interaksi antara pemohon dengan petugas perizinan dan menghindari pungutan-pungutan tidak resmi.

Pelayanan Perizinan Terpadu bertujuan untuk memberikan akses yang lebih luas kepada masyarakat untuk memperoleh pelayanan publik. Sasaran utama pelayanan publik adalah terwujudnya pelayanan publik yang cepat, murah, 
transparan, pasti dan terjangkau serta meningkatkan hak-hak masyarakat terhadap pelayanan publik. Perangkat Daerah Penyelenggara Pelayanan Terpadu Satu Pintu selanjutnya adalah perangkat pemerintah daerah yang memiliki tugas pokok dan fungsi mengelola semua bentuk pelayanan perizinan dan non perizinan di daerah dengan sistem satu pintu.

Upaya yang dilakukan pemerintah dalam meningkatkan pelayanan dalam hal perizinan adalah melalui ditetapkannya Keputusan Menteri Dalam Negeri Nomor 24 Tahun 2006 tentang Pelayanan Terpadu Satu Pintu yang bertujuan untuk meningkatkan kualitas layanan publik serta memberikan akses yang lebih luas kepada masyarakat untuk memperoleh pelayanan publik serta sasaran penyelenggaraan Pelayanan Terpadu Satu Pintu adalah terwujudnya pelayanan publik yang cepat, murah, mudah, transparan, pasti dan terjangkau, meningkatnya hak-hak masyarakat terhadap pelayanan pubik.

\subsection{Kualitas Pelayanan}

Berbicara tentang pelayanan publik tidak dapat terlepas dari kualitas pelayanan publik yang menyangkut akses pelayanan. Kualitas pada dasarnya merupakan kata yang menyandang arti reratif karena bersifat abstrak, kualitas dapat digunakan untuk menilai atau menentukan tingkat penyesuaian suatu hal terhadap persyaratan atau spesifikasinya. Bila persyaratan atau spesifikasi itu terpenuhi berarti kualitas sesuatu hal yang dimaksud dapat dikatakan baik, sebaiknya jika persyaratan tidak terpenuhi maka dapat dikatakan tidak baik.

Menurut Goetsch \& Davis dalam Hardiyansyah (2011:36), menyatakan bahwa kualitas pelayanan adalah sesuatu yang berhubungan dengan terpenuhinya harapan/kebutuhan pelanggan, dimana pelayanan dikatakan berkualitas apabila dapat menyediakan produk dan jasa (pelayanan) sesuai dengan kebutuhan dan harapan pelanggan. Dalam hal ini, kualitas pada dasarnya terkait dengan pelayanan yang baik, yaitu sikap atau cara karyawan dalam melayani pelanggan atau masyarakat secara memuaskan. Kualitas pelayanan adalah kegiatan yang di berikan penyedia layanan sesuai dengan apa yang didambakan oleh masyarakat dan baik, kualitas pengertian trasional maupun modern sama-sama adalah untuk menjamin kepuasan masyarakat.

\section{METODE PENELITIAN}

\subsection{Jenis Penelitian}

Jenis penelitian ini adalah penelitian deskriptif dengan menggunakan pendekatan kualitatif. Penelitian ini menggunakan analisis institusionalisme karena penelitian ini dilakukan pada suatu bagian organisasi pemerintahan. Pierson \& Skocpol (2008), menyatakan bahwa analisis institusional digunakan untuk mengkaji segala sesuatu dari proses legislatif, efek terhadap gerakan sosial, sampai politik hukum.

\subsection{Lokasi Penelitian}

Penelitian dilaksanakan di Dinas Penanaman Modal dan Pelayanan Terpadu Satu Pintu Kota Gorontalo.

\subsection{Pengumpulan Data}

Teknik pengumpulan data yag digunakan dalam penelitian yaitu dengan menggunakan wawancara mendalam, dan dokumentasi. Wawancara mendalam (Indepth Interview), yaitu teknik pengumpulan data dimana peneliti secara langsung mengadakan tanya jawab dengan Kepala Dinas Penanaman Modal dan 
Pelayanan Terpadu Satu Pintu Kota Gorontalo dan elemen terkait lainnya. Dokumentasi, yaitu teknik pengumpulan data yang dilakukan untuk mendokumentasikan semua data dan informasi yang diperoleh di Dinas Penanaman Modal dan Pelayanan Terpadu Satu Pintu Kota Gorontalo.

\subsection{Analisis Data}

Menurut Norman (2009), kegiatan analisis data kualitatif mencakup pengujian, mengerutkan, mengkategorikan, mengevaluasi, membandingkan, mensintesiskan dan mengkontemplasikan data yang dikode seperti halnya interview data mentah dan data yang direkam. analisis data yang dilakukan dalam penelitian ini melalui analisis kualitatif dengan tahapan pengelolaan data yaitu penafsiran data, reduksi data, penyusunan data, pemeriksaan keabsahan data, Menarik kesimpulan.

\section{HASIL PENELITIAN DAN PEMBAHASAN}

\subsection{Pelaksanaan Reformasi Pubilik di Dinas Penanaman Modal dan} Pelayanan Terpadu Satu Pintu Kota Gorontalo.

Hasil penelitian menunjukkan bahwa reformasi pelayanan publik di Dinas Penanaman Modal dan Pelayanan Terpadu Satu Pintu Kota Gorontalo dilihat dari struktur, prosedur, proses belum berjalan dengan baik namun dari unsur tingkah laku sudah menunjukkan adanya perubahan sikap aparatur yang baik dalam memberikan pelayanan.

Untuk menjelaskan tentang pelaksanaan reformasi pelayanan perizinan digunakan digunakan teori dari Khan (1981) \& Quah (1976) yang menyatakan bahwa reformasi sebagai suatu usaha perubahan pokok dalam suatu sistem birokrasi yang bertujuan mengubah struktur, prosedur, proses, dan tingkah laku. Pembahasannya adalah sebagai berikut:

\subsubsection{Struktur}

Indikator reformasi/perubahan struktur yang pertama adalah sentralisasi. Temuan di lapangan menunjukkan bahwa struktur di Dinas Penanaman Modal dan Pelayanan Terpadu Satu Pintu Kota Gorontalo masih hirarki, Kepala Dinas memegang kewenangan peranan penting atas pengambilan keputusan. Meskipun sering sebelum mengambil keputusan, Kepala Dinas mengadakan rapat dengan para Kepala Seksi, dan kadang dengan para staff namun semua keputusan adalah hak penuh Kepala Dinas. Reformasi/ perubahan struktur dengan indikator sentralistik bersesuaian dengan teori Kast \& Rosenzweig (2002:281) yang menyatakan bahwa sentralisasi-formalisasi kewenangan merupakan komponen dari teori tertutup (closed system theory) yang menunjukkan relasi antar subsistem secara hirarkis dari atas ke bawah

Formalisasi merupakan salah satu aspek dari struktur organisasi dimana pekerjaan dalam suatu organisasi didistribusikan, dimasukkan dalam suatu aturan-aturan, prosedur-prosedur dan perintah dalam bentuk tertulis. Fakta dilapangan menunjukkan SOP menjadi pedoman bagi aparat dalam melaksanakan tugas di Dinas Penanaman Modal dan Pelayanan Terpadu Satu Pintu Kota Gorontalo sehingga mereka tidak mempunyai kreatifitas karena harus sesuai dengan aturan yang berlaku. Hal ini bersesuaian dengan teori dari Robbins (1994:103) yang menyatakan jika sebuah pekerjaan sangat diformalisasikan, maka pemegang pekerjaan itu hanya mempunyai sedikit kebebasan mengenai apa yang harus dikerjakan, bilamana mengerjakannya, 
dan bagaimana ia harus melakukannya. Formalisasi juga merupakan tingkat dimana suatu organisasi menggunakan peraturan dan prosedur tertulis untuk menentukan perilaku karyawannya (Gibson, 1985). Spesialisasi dalam suatu organisasi tidak terlepas dari struktur organisasi sebagai pola hubungan antara individu dalam suatu kelompok dalam melaksanakan tugas atau pekerjaan secara formal dibagikan kepada kelompok dan di koordinasikan sehingga merupakan satu kesatuan yang harmonis kemudian diarahkan untuk suatu tujuan tertentu.

Fakta di lapangan menunjukkan bahwa terdapat pengelompokkan pekerjaan ke dalam Seski-Seksi yaitu Seksi Perizinan, Seksi Pelayanan dan Seksi Keuangan, selain itu ada tim teknis yang bertugas untuk penelitian lapangan. Pengelompokkan pekerjaan menjadikan para aparat di Dinas Penanaman Modal dan Pelayanan Terpadu Satu Pintu Kota Gorontalo menjadi mudah dalam menyelesaikan pekerjaannya. Hal ini bersesuaian dengan teori Kast dan Rosenzweig (2002) yang menyatakan desain tugas yang dirancang untuk mempermudah pelaksanaan kegiatan organisasi.

\subsubsection{Prosedur}

Prosedur merupakan rangkaian proses atau tata kerja yang berkaitan satu sama lain, oleh sebab itu prosedur harus mudah dipahami serta dapat diimplementasikan dengan baik dan konsisten. Fakta di lapangan prosedur pelayanan perizinan masih panjang dan melibatkan dinas terkait untuk mendapatkan surat rekomendasi sehingga masyarakat selain mengikuti prosedur yang ada di Dinas Penanaman Modal dan Pelayanan Terpadu Satu Pintu Kota Gorontalo, masih juga mengikuti prosedur di dinas terkait seringkali prosedurnya sama. Hal ini bersesuaian dengan teori Richard F. Neuschel (1971) suatu prosedur adalah suatu urut-urutan kegiatan klerikal, biasanya melibatkan beberapa orang di dalam satu atau lebih departemen, yang diterapkan untuk menjamin penanganan yang seragam dari transaksi-transaksi bisnis yang terjadi

\subsubsection{Proses}

Proses sangat menentukan kegiatan pelayanan. Lambat atau cepatnya suatu pelayanan ditentukan oleh proses yang berhubungan dengan waktu. Proses adalah menyangkut adalah urutan pelaksanaan atau kejadian yang terjadi secara alami atau didesain menggunakan waktu. Indikator dari proses adalah waktu. Fakta di lapangan bahwa proses pengurusan perizinan belum sesuai dengan waktu yang telah ditetapkam di Dinas Penanaman Modal dan Pelayanan Terpadu Satu Pintu Kota Gorontalo. Untuk mengurus IMB (Izin Mendirikan Bangunan) masyarakat harus menuggu selama 20 hari kerja padahal waktu yang ditetapkan adalah 14 (empat belas) hari kerja. Demikian pula pengurusan Surat Izin Usaha Perdagangan (SIUP) berdasarkan aturan 3 (tiga) hari kerja tetapi ternyata masyarakat menerima surat izin pada hari ke 5 hari kerja. Hal ini bersesuai dengan teori Frederik Monte (2008) menyebutkan bahwa untuk menilai pelayanan yang berkualitas dapat digunakan kriteria-kriteria antara lain kejelasan dan kepastian yaitu yang menyangkut jadwal waktu penyelesaian pelayanan

\subsubsection{Tingkah Laku/ Perilaku}

Perubahan tingkah laku/prilaku dapat diamati dengan memperhatikan, menghayati, menerangkan apa yang terjadi dalam proses kejiwaan. Fakta di lapangan para aparat Dinas Penanaman Modal dan Pelayanan Terpadu Satu 
Pintu Kota Gorontalo dalam melaksanakan tugas, mempunyai ketaaatan pada aturan. Hal ini terlihat aparat dalam melaksanakan tugas selalu berpedoman pada aturan yang berlaku baik yang tertulis maupun perintah secara lisan dari pimpinan. Selain itu mereka tekun dalam bekerja, menyelesaikan tugas dengan baik, serta bertanggung jawab atas pekerjaan. Para karyawan selalu disipin hal ini dapat dilihat datang tepat waktu dan selama jam kerja selalu berada di loketloeket pelayanan. Hal ini bersesuai dengan teori Fisher \& Gochros (1975) yang menyatakan bahwa pengubahan perilaku adalah penerapan yang terencana dan sistematis dari prinsip belajar yang telah ditetapkan untuk mengubah perilaku mal adaptif (Fischer 1975).

\subsubsection{Komitmen aparat}

Agar supaya pelaksanaan reformasi pelayanan perizinan berjalan dengan baik dibutuhkan komitmen antara Kepala Dinas Penanaman Modal dan Pelayanan Terpadu Satu Pintu Kota Gorontalo dengan para Kepala Dinas dan Badan yang mempunyai kewenangan mengeluarkan surat rekomendasi untuk mengesampingkan rasa egonya untuk secara bersama-sama berkomitmen meningkatkan kualitas pelayanan perizinan. Menurut Van Dyne dan Graham (2005) faktor-faktor yang mempengaruhi komitmen organisasi adalah personal, situasional dan posisi. Reformasi komitmen aparat bersesuaian dengan teori Conner dan Patterson (1982) yag menyatakan faktor yang paling umum yang berkontribusi terhadap kegagalan dari suatu proyek perubahan adalah kurangnya komitmen oleh pegawai.

\subsubsection{Teknologi Informasi}

Tekhnologi informasi sangat berpengaruh terhadap pelaksanaan reformasi pelayanan perizinan di Dinas Penanaman Modal dan Pelayanan Terpadu Satu Pintu Kota Gorontalo. Indikator yang digunakan pada proses reformasi tekhnologi informasi yaitu: pertama, persepsi mengenai mamfaat, dan kedua kemudahan mengunakan tekhnologi.

Untuk indikator yang pertama, fakta di lapangan menunjukkan bahwa Dinas Penanaman Modal dan Pelayanan Terpadu Satu Pintu Kota Gorontalo telah mempunyai Webside secara online yang membantu masyarakat mengetahui informasi tentang pengurusan perizinan. Selain itu tersedia pula informasi mengunakan handpone melalui jaringan sms. Adanya tekhnologi informasi sangat berguna bagi para pegawai dalam pelaksanaan tugas memberikan pelayanan kepada masyarakat. Indikator yang ke dua sebagian besar pegawai mempunyai kemampuan untuk mengunakan komputer, membuka internet sehingga dapat meningkatkan kinerjanaya.

\subsection{Faktor Determinan Reformasi Pelayanan Publik di Dinas Penanaman Modal dan Pelayanan Terpadu Satu Pintu Kota Gorontalo}

\subsubsection{Kesadaran Aparat yang Berkecimpung dalam Pelayanan}

Pentingnya kesadaran para pejabat atau petugas yang berkecimpung dalam tugas pelayanan menunjukkan suatu keadaan pada jiwa seseorang yaitu merupakan titik temu atau equilibrium dari berbagai pertimbangan sehingga diperoleh suatu keyakinan, ketenangan, ketetapan hati dan keseimbangan dalam jiwa yang bersangkutan. Fakta di lapangan menunjukkan bahwa aparat bersikap ramah kepada masyarakat, memberikan membantu menyampaikan infrormasi yang jelas tentang pelayanan perizinan kepada masyarakat, mendengarkan keluhan masyarakat 


\subsubsection{Faktor Aturan}

Untuk membantu aparat Dinas Penanaman Modal dan Pelayanan Terpadu Satu Pintu Kota Gorontalo ketika melaksanakan tugas, dibuat SOP (Standar Operasional Prosedur) meskipun masih berlaku secara intern yang menjadi pedoman bagi aparat dalam melaksanakan tugas memberikan pelayanan perizinan kepada masyarakat. Selain itu mengatur tatacara masyarakat yang mengurus perizinan yang dituangkan ke dalam prosedur pengurusan peizinan. Adanya SOP (Standar Operasional Prosedur) menjadikan aparat mengetahui apa saja saja yang akan dikerjakan dalam suatu proses pelayanan serta masyarakat yang mengurus perizinan juga mengetahui apa saja yang akan dilakukan untuk mengurus surat izin di Dinas Penanaman Modal dan Pelayanan Terpadu Satu Pintu Kota Gorontalo.

\subsubsection{Faktor Organisasi}

Organisasi sebagai kesatuan sosial terdiri dari orang atau kelompok orang yang berinteraksi satu sama lain. Pola interaksi yang diikuti oleh anggota organisasi tidak begitu saja timbul, melainkan telah dipikirkan terlebih dahulu. Indikator yang digunakan yaitu kerjasama. Fakta di lapangan menunjukkan bahwa kerjasama antara aparat berjalan baik. Kerjasama antara aparat mulai terjalin dari petugas di loket informasi berjumlah 4 orang yang terdiri dari 2 orang dari staff Seksi perizinan dan 2 orang dari staff seksi pelayanan. Selanjutnya pada loket pelayanan berjumlah 3 orang terdiri dari terdiri dari 1 orang staff pelayanan, 1 orang staff periizinan dan 1 orang staff keuangan. pemahaman atau persepsi aparat perlunya kerjasama yang baik antara aparat di Dinas Penanaman Modal dan Pelayanan Terpadu Satu Pintu Kota Gorontalo berkat adanya pembinaan yang selalu dilakukan oleh Kepala Dinas pada setaip apel, yang menekankan pentingnya kerjasama untuk mencapai tujuan organisasi. Hal ini bersesuaian dengan teori Robbins (1996) persepsi akan memunculkan suatu tanggapan berupa dukungan pada karakteristik organisasi yang selanjutnya mempengaruhi kinerja karyawan. Ini menyatakan bahwa faktor organisasi sangat mendukung reformasi pelayanan perizinan di Dinas Penanaman Modal dan Pelayanan Terpadu Satu Pintu Kota Gorontalo.

\subsubsection{Faktor Pendapatan}

Pendapatan sangat penting bagi pegawai untuk meningkatkan kesejahteraan pribadi maupun keluarganya. Fakta di lapangan PNS di Dinas Penanaman Modal dan Pelayanan Terpadu Satu Pintu Kota Gorontalo bagi yang memegang jabatan. Sedangkan bagi Tenaga Penunjang Kegiatan (TPK) menerima insentif yang dibayarkan perbulan oleh Pemerintah daerah Kota Gorontalo. Faktor pendapatan ini sebagai salah satu motivasi bagi aparat dan berpengaruh terhadap kinerja. Dengan adanya pendapatan yang wajar, yang diterima aparat Dinas Penanaman Modal dan Pelayanan Terpadu Satu Pintu Kota Gorontalo dapat meningkatkan kesejahteraan hidup baik bagi secra individu maupun keluarganya.

\subsubsection{Faktor Keterampilan}

Keterampilan sangat penting pagi pegawai agar supaya bekerja lebih profesional. Fakta di lapangan pegawai yang sudah mengikuti pelatihan sebanyak 15 orang yang dilaksanakan baik tingkat Nasional maupun tingkat lokal. Adapun pelatihan pernah diikuti oleh pegawai yaitu pelatihan tentang pelayanan, pelatihan keuangan, pelatihan penanganan dan pengaduan yang dilaksanakan oleh bank, Badan Pemeriksa Keuangan (BPK), Badan Pemeriksa Keuangan Pembangunan (BPKP), dan Obusmen. Pegawai yang sudah pernah 
mengikuti pelatihan akan berkerja lebih baik lagi jika dibandingkan sebelum mengikuti pelatihan. Hal ini sangat mendukung reformasi pelayanan publik di Dinas Penanaman Modal dan Pelayanan Terpadu Satu Pintu Kota Gorontalo.

\subsubsection{Faktor Sarana}

Ketersediaan sarana pelayanan yang memadai yaitu ruang tunggu yang nyaman tang dilengkapi AC, dispenser, komputer, foto copy, mesin printer, sejumlah kursi untuk tempat duduk. Selain itu disediakan koran,majalah, sehingga pemohon yang sedang antri merasa nyaman dalam ruangan. Demikian juga disetiap ruangan pegawai dipasang AC dan dilengkapi leptop untuk membantu pegawai dalam melaksanakan tugas-tugasnya. Faktor ini sangat mendukung reformasi pelayanan publik di Dinas Penanaman Modal dan Pelayanan Terpadu Satu Pintu Kota Gorontalo. Kelengkapanan sarana yang dimilki oleh Dinas Penanaman Modal dan Pelayanan Terpadu Satu Pintu Kota Gorontalo dapat dilihat pada tabel 4.1.

Tabel 4.1 Sarana Pendukung di Dinas Penanaman Modal dan Pelayanan Terpadu Satu Pintu Kota

\begin{tabular}{|c|c|c|c|}
\hline No & Nama & Bahan & Jumlah Barang \\
\hline 1. & Mesin Pendingin ruangan & Elektronik & buah \\
\hline 2. & Komputer & Elektronik & buah \\
\hline 3. & Televisi & Elektronik & buah \\
\hline 4. & Printer & Elektronik & buah \\
\hline 5. & Dispenser & Elektronik & buah \\
\hline 6. & Mesin Hitung & Elektronik & buah \\
\hline 7. & Leptop & Elektronik & 4 buah \\
\hline 8. & Meja Kerja & Kayu & 14 buah \\
\hline 9. & Meja Komputer & Kayu & 7 buah \\
\hline 10. & Kursi Kerja & Kayu & 20 buah \\
\hline 11. & Kursi Sofa tamu & Kayu & 2 buah \\
\hline 12. & Kursi biru & Stenlis & 40 buah \\
\hline 13. & Lemari & Kayu & 5 buah \\
\hline
\end{tabular}

Sumber: Dinas Penanaman Modal dan Pelayanan Terpadu Satu Pintu Kota Gorontalo

\subsubsection{Biaya Perizinan}

Fakta di lapangan menunjukkan bahwa masyarakat banyak mengeluh tentang biaya yang dibayarkan sewaktu mengurus perizinan. Kurangnya informasi tentang perincian biaya yang harus dibayar untuk mengurus surat izin menyebabkan banyak komplain masyarakat yang disampaikan ke bagian pengaduan Dinas Penanaman Modal dan Pelayanan Terpadu Satu Pintu Kota Gorontalo. Faktor ini yang menjadi penghambat reformasi pelayanan publik di Dinas Penanaman Modal dan Pelayanan Terpadu Satu Pintu Kota Gorontalo.

\subsubsection{Persyaratan}

Fakta di lapangan menunjukkan masyarakat sering mengeluh karena banyak persyaratan yang harus di lengkapi untuk mengurus perizinan. Untuk membuka usaha salah satu syarat yang harus dipenuhi yaitu melampirkan 10 (sepuluh) pernyataan tidak keberatan dilengkapi foto copy KTP dari para kepala keluarga tetangga terdekat. Faktor ini menjadi penghambat reformasi pelayanan 
publik di Dinas Penanaman Modal dan Pelayanan Terpadu Satu Pintu Kota Gorontalo.

Temuan peneliti selain faktor biaya dan persyaratan masih ada lagi yang menjadi faktor penghambat reformasi pelayanan publik yaitu:

1. Kepala Dinas tidak mempunyai kewenangan mengawasi Tim Tekhnis di lapangan, padahal tim teknis termasuk dalam struktur di Dinas Penanaman Modal dan Pelayanan Terpadu Satu Pintu Kota Gorontalo.

2. Tidak adanya pengawasan terpadu atas cara kerja di Dinas Penanaman Modal dan Pelayanan Terpadu Satu Pintu Kota Gorontalo, karena belum ada aturan yang memberikan kewenangan Dinas Penanaman Modal dan Pelayanan Terpadu Satu Pintu Kota Gorontalo untuk mengawasi tim teknis yang ada di lapangan. Pengawasan terhadap hasil kerja tim teknis dilaksanakan oleh masing-masing Dinas terkait. Tidak adanya pengawasan secara terpadu tersebut menimbulkan masalah ketika izin diterbitkan.

Peneliti menyimpulkan bahwa dalam reformasi pelayanan perizinan terpadu perlu menambahkan perubahan komitmen dan teknologi informasi. Dengan bertambahnya perubahan komitmen dan perubahan teknologi, pandangan ini akan berbeda dengan apa yang dikemukakan oleh Khan (1981) dan Quah (1976) tentang reformasi yang menyatakan bahwa reformasi sebagai suatu usaha perubahan pokok dalam suatu sistem birokrasi yang bertujuan mengubah struktur, prosedur, proses, dan tingkah laku.

Kedua unsur ini merupakan sasaran perubahan organisasi yang digunakan peneliti untuk memodifikasi reformasi pelayanan yang dikemukakan oleh Khan (1981) dan Quah (1976). Dalam konteks ini peneliti menegaskan formulasi baru yang menjadi enam sasaran reformasi yaitu perubahan struktur, prosedur, proses tingkah laku. Keenam unsur ini kiranya dapat diterapkan dan diwujudkan pada pelaksanaan reformasi pelayanan perizinan di Dinas Penanaman Modal dan Pelayanan Terpadu Satu Pintu Kota Gorontalo. Penerapan konsep yang ditawarkan hendaknya disesuaikan dengan karakteristik perubahan masing masing organisasi. Enam unsur ini saling dikombinasikan karena saling berhubunga satu dengan lainnya. Dengan demikian hasil studi ini mengimplikasikan pada sebuah pemikiran baru untuk para pengambil keputusan bahwa unsur-unsur ini sangat penting untuk melakukan suatu perubahan dalam bidang pelayanan perizinan.

\section{PENUTUP}

\subsection{Kesimpulan}

Sebagai kesimpulan dari hasil penelitian dan pembahasan yang telah diuraikan, maka dapat dipertegas beberapa hal sebagai berikut:

1. Reformasi pelayanan perizinan di Dinas Penanaman Modal dan Pelayanan Terpadu Satu Pintu Kota Gorontalo dalam pelaksanaannya struktur organisasi menjadi lebih hirarkhi, mekanistik; prosedur mengacu pada Standar Opersional Prosedur (SOP) menjadi lebih panjang; proses pengurusan perizinan tidak sesuai dengan waktu yang telah ditetapkan, tingkah laku/prilaku aparat menjadi lebih baik.

2. Faktor determinan yang mempengaruhi reformasi pelayanan perizinan di Dinas Penanaman Modal dan Pelayanan Terpadu Satu Pintu Kota Gorontalo menunjukkan a)Kesadaran para aparat; b) Faktor aturan; c) faktor organisasi; (d) faktor pendapatan; (e) Keterampilan, adalah faktor 
pendukung yang perlu dipertahankan sedangkan faktor biaya, persyaratan, tidak adanya kewenangan Kepala Dinas kepada tim teknis serta tidak adanya Tidak adanya pengawasan terpadu atas cara kerja di Dinas Penanaman Modal dan Pelayanan Terpadu Satu Pintu Kota Gorontalo, karena belum ada aturan yang memberikan kewenangan Dinas Penanaman Modal dan Pelayanan Terpadu Satu Pintu Kota Gorontalo untuk mengawasi tim teknis yang ada di lapangan. Pengawasan terhadap hasil kerja tim teknis dilaksanakan oleh masing-masing Dinas terkait. Tidak adanya pengawasan secara terpadu tersebut menimbulkan masalah ketika izin diterbitkan.

Pengawasan terpadu atas cara kerja di Dinas Penanaman Modal dan Pelayanan Terpadu Satu Pintu Kota Gorontalo, merupakan faktor penghambat yang sebaiknya dihilangkan dalam pelaksanaan reformasi pelayanan perizinan di Dinas Penanaman Modal dan Pelayanan Terpadu Satu Pintu Kota Gorontalo.

\subsection{Saran}

Berdasarkan kesimpulan penelitian sebagaimana yang telah dikemukakan di atas, maka peneliti merekomendasikan beberapa saran sebagai berikut:

1. Hendaknya reformasi pelayanan perizinan di Kota Gorontalo perlu ditingkat dengan menjadikan Dinas Penanaman Modal dan Pelayanan Terpadu Satu Pintu Kota Gorontalo strukturnya lebih ramping dan ditempatkan perwakilan pegawai dari instansi terkait yang mempunyai keahlian bidang perizinan di Dinas Penanaman Modal dan Pelayanan Terpadu Satu Pintu Kota Gorontalo, prosedur pengurusan perizinan dibuat lebih sederhana dengan meniadakan penerbitan rekomendasi dari dinas terkait, proses pengurusan perizinan dibuat lebih cepat sehingga memudahkan masyarakat dalam mengurus perizinan.

2. Hendaknya faktor determinan yang berpengaruh terhadap reformasi pelayanan publik di Dinas Penanaman Modal dan Pelayanan Terpadu Satu Pintu Kota Gorontalo dijadikan referensi dan evaluasi oleh Pemerintah Kota Gorontalo untuk membuat kebijakan yang lebih mendorong percepatan reformasi pelayanan publik di Dinas Penanaman Modal dan Pelayanan Satu Pintu Kota Gorontalo Dinas Penanaman Modal dan Pelayanan Terpadu Satu Pintu Kota Gorontalo sehingga dapat meningkatkan kualitas pelayanan publik

\section{DAFTAR PUSTAKA}

Abdul, Wahab. 2000 Analisis Kebijaksanaan dari Formulasi ke Implementasi Kebijkan Negara. Bumi Aksara : Jakarta

Evans, James R. dan William M. Lindsay. 2007. An Introduction to Six Sigma \& Process Improvement (Pengantar Six Sigma). Jakarta : Penerbit Salemba Empat.

Fischer \& Gochros, 1975 Planned behavior Change, Behavior Modification in New York

Gibson 1985 Gibson.et.al. 1985 Organisasi: Prilaku, Struktur dan Proses. Jakarta: Erlangga

Gibson, Ivan Cevich, Donelly. 1995 Organisasi. alih bahasa Nunuk Adiarni, edisi Kedelapan. Jakarta: Bina rupa Aksara

Hasibuan 2002 Manajemen dasar, pengertian dan masalah Jakarta: Haji masagung 
Inpres Nomor 1995 tentang Perbaikan dan Peningkatan Mutu Pelayanan Aparatur Pemerintah kepada Masyarakat.

Jerry Fitz Gerald dkk 1981.Fundamentals System Analysis (2nd Edition). NewYork: John Willey \& Sons Inc.

Kast, F.E and Rosenzweig, J.E.2002 Organisasi dan Manajemen.Terjemahan Hasyim Ali, Jakarta: Bumi Aksara.

Keputusan Menteri Pendayagunaaan Aparatur Negara Nomor 63/KEP/M.PAN/7/2003 pengertian umum pelayanan publik

Khan 1981 Comparative study of grain yield andbiochemical traits of different rice varieties grown under saline and normal conditions. The J. of Animal \& Plant Scie., 23(2):575-588.

Peraturan Daerah Nomor 14 Tahun 2006 tentang Organisasi dan Tata Kerja Pemerintah Kota Gorontalo.

Peraturan Menteri Dalam Negeri Nomor 24 Tahun 2006 tentang Pelayanan Terpadu Satu Pintu

Ribert Kwick 1974. Measurement of Malows Need Hirarchy. Journal of

Ridwan Juniarso 2009 Hukum Administrasi Negara dan Kebijakan Pelayanan Publik. Bandung : Nuansa.

Robbins., Stephen P 1994.. Teori Organisasi : Struktur, Desain, dan Aplikasi, Edisi Ketiga, Alih Bahasa Jusuf Udaya, Arcan, Jakarta

Robbins, S.P. 1996 Perilaku Organisasi. Jakarta : Prenhallindo.

Sinambela 2008. Reformasi Pelayanan Publik. Jakarta: Bumi Aksara

Surat Keputusan Menteri Pendayagunaan Aparatur Negara Nomor 81 Tahun 1993 tentang Pedoman Tatalaksana Pelayanan Umum

Undang-Undang Nomor 25 tahun 2009 tentang Pelayanan Publik

Van, Dyne, L, Graham J.W. 2005. Organizational Citizenship Behavior; Construct Redefinition Measurement and Validation.Academiy Management Journal, 37 (4) pp 765-802.

Quah, J.S.T., 1976. Administrative Reform: A Conceptual Analysis. Philippine Journalof Public Administration, Vol. 20, No. 1, pp. 50-67. 